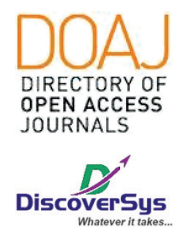

Published by DiscoverSys

\section{Awareness of breast cancer risk factors and practice of breast self - examination among female students in Medical Faculty, Udayana University, Bali}

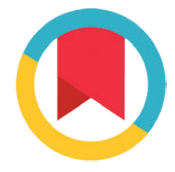

CrossMark

\author{
Shalini Kalithasan, ${ }^{1 *}$ Gede Eka Rusdi Antara²
}

\section{ABSTRACT}

Background: Breast cancer patients generally have low rates of survival rates due to late-stage diagnosis as patients usually present at and late stage because of lack of awareness and ignorance of risk factors. Methods: The objectives of this study are to evaluate the knowledge of risk factor for breast cancers and the practice of breast selfexamination among female students in medical faculty at Udayana University. A cross sectional study conducted over a period of one

month. 100 female students were volunteered to take part in the survey. The data were analyzed descriptively.

Results: A half of the students have moderate knowledge of breast cancer risk factors, and the majority of the students do not practice breast self-examination monthly.

Conclusions: It was suggested to students have more concern about relevant education programs that are having around them.
Keywords: breast self - examination, student

Cite This Article: Kalithasan, S., Antara, G.E.R. 2019. Awareness of breast cancer risk factors and practice of breast self - examination among female students in Medical Faculty, Udayana University, Bali. Intisari Sains Medis 10(1): 28-31. D0I: 10.1556/ism.v10i1.320

\title{
ABSTRAK
}

Latar Belakang: Pasien kanker payudara umumnya memiliki tingkat rendah tingkat kelangsungan hidup karena diagnosis tahap akhir karena pasien biasanya hadir pada dan tahap akhir karena kurangnya kesadaran dan ketidaktahuan faktor risiko.

Metode: Tujuan dari penelitian ini adalah untuk mengevaluasi pengetahuan tentang faktor risiko kanker payudara dan praktek pemeriksaan payudara sendiri di antara siswa perempuan di fakultas kedokteran universitas Udayana. Studi cross sectional dilakukan selama satu bulan dengan 100 siswa perempuan sebagai sampel. Data dianalisis dengan studi deskriptif.

Hasil: Setengah dari siswa memiliki pengetahuan menengah tentang faktor risiko kanker payudara dan sebagian besar siswa tidak melakukan pemeriksaan payudara sendiri setiap bulan.

Simpulan: Disarankan agar siswa memiliki lebih banyak perhatian tentang program pendidikan yang relevan yang ada di sekitar mereka.

Kata kunci: pemeriksaan payudara sendiri, siswa

Cite Pasal Ini: Kalithasan, S., Antara, G.E.R. 2019. Awareness of breast cancer risk factors and practice of breast self - examination among female students in Medical Faculty, Udayana University, Bali. Intisari Sains Medis 10(1): 28-31. D0I: 10.1556/ism.v10i1.320

${ }^{1}$ Medical Education Program, ${ }^{2}$ Department of Surgery RSUP Sanglah

Medical Faculty of Udayana University
*Corresponding: Shalini Kalithasan, Medical Education Program, Medical Faculty of Udayana University shalinikalithasan1194@gmail.com

Received: 2018-10-02 Accepted: 2018-10-07 Published: 2019-04-01

\section{INTRODUCTION}

Breast cancer is the common development of malignant cells in the breast. Breast cancer is caused by the differentiation and proliferation of breast epithelial cells mediated by hormonal factors. ${ }^{1}$ It is the most common cancer found in Indonesian women. According to the latest WHO data published in May 2014 Breast Cancer Deaths in Indonesia reached 19,739 or $1.41 \%$ of total deaths. The age adjusted Death Rate is 19.02 per 100,000 of population Indonesia. ${ }^{2}$

Survival rates for breast cancer patients are generally low due to late-stage diagnosis as patients usually present at an advanced stage because of lack of awareness and ignorance of risk factors.
Awareness about breast cancer different among populations groups worldwide. Generally, patients with a high level of awareness usually present with early stages of breast cancers as a result of the adoption of screening methods, while patients from low-level communities have little knowledge or awareness about breast cancer. ${ }^{3}$

Mammography, breast self-examinations, and clinical breast examinations are regular examinations which used for breast cancer screening. These examinations are widely recommended by physicians to reduce breast cancer mortality. ${ }^{4}$ Women of all ages are encouraged to do breast self-examination which knew as "breast aware," which is useful to 
make an earlier diagnosis of breast cancer. Women must learn to assess the knowledge of breast cancer risk factor. It would improve their level of breast cancer risk factors awareness. ${ }^{2}$

Patients with breast cancer believe that physicians are controlling the pain. A top average score for breast cancer pain will be recorded in the positive coping self-statement subscale among pain coping strategies. Level of breast cancer acceptance of patients depends on their income. ${ }^{5}$

Studies proved that young women are more likely to get breast cancer because of contraceptive pills, nulliparity, advancing age at first childbirth, consumption of alcohol, unhealthy diet, and smoking habit. Most of the young women normally characterized by female university undergraduates are conscious of the information that some of these lifestyle habits create risk factors for breast cancer. ${ }^{3}$

\section{METHODS}

This study was a descriptive cross-sectional study to investigate the sociodemographic background of the participants influencing their level of awareness on the breast cancers to risk factors and use of breast self-examination as a cancer screening program. This study was conducted at Udayana University in November 2016. The sample in this study was taken from the female students of the Faculty of Medicine which fulfilled the inclusion criteria. The inclusion criteria were from batch
2013-2015 in the Faculty of Medicine, stable mental status, and join the research willingly. 100 samples were taken using consecutive sampling technique. The samples were interviewed to obtain the data used to fill out the questionnaire. Descriptive analysis processed the data.

\section{RESULT}

Hundred female students agreed to participate in the study and returned the filled questionnaires. $37 \%$ were within the age range of $16-19$ years, $60 \%$ were within the age range of $20-23,2 \%$ were within the age range of $24-27,1 \%$ were within the age range of $28-31.36 \%$ of the respondent was in the $2^{\text {nd }}$ year of the study, $35 \%$ in the $3^{\text {rd }}$ year and $29 \%$ in the $4^{\text {th }}$ year. All of them (100\%) were single. $52 \%$ of them knew someone who has been diagnosed with breast cancer and forty-eight $48 \%$ did not know any breast cancer individuals.

Participants knowledge regarding the risk factors for breast cancer were inquired using questionnaires. The participants were asked to mark yes as many things as they consider risk factors from a list. The percentage of those who answered correctly for each item was presented in Table 1.

The answers of participants about how often of breast self - examination should be performed were presented in Table 2 and the Awareness of participants about breast self - examination were presented in Table 3.

Table 1 Knowledge of Breast Cancer Risk Factor

\begin{tabular}{lcc}
\hline Breast Cancer Risk Factor & $\begin{array}{c}\text { Frequency } \\
(\mathbf{n = 1 0 0 )}\end{array}$ & $\begin{array}{c}\text { Percentage } \\
\text { (\%) }\end{array}$ \\
\hline The family history of breast cancers & 82 & 82,0 \\
Sedentary lifestyle & 55 & 55,0 \\
Stressful lifestyle & 62 & 62,0 \\
Alcohol consumption & 66 & 66,0 \\
Cigarette smoking & 65 & 65,0 \\
Drugs abuse & 57 & 57,0 \\
Hormonal replacement therapy & 68 & 68,0 \\
High fat consumption & 68 & 68,0 \\
Obesity & 65 & 65,0 \\
Oral contraceptives & 58 & 58,0 \\
A hard blow to the breast & 48 & 48,0 \\
Wearing tight bras & 57 & 57,0 \\
Radiation exposures & 75 & 75,0 \\
Exposure to chemical in cosmetic & 54 & 54,0 \\
Irregular menstruation history & 52 & 52,0 \\
Early sexual debut & 47 & 47,0 \\
Pregnancy or abortion history & 51 & 51,0 \\
\hline
\end{tabular}


Table 2 The Answers of Participant about How often of breast self examination should be performed

\begin{tabular}{lcc}
\hline $\begin{array}{l}\text { The frequency of Breast } \\
\text { Self - Examination Should Be } \\
\text { Performed }\end{array}$ & $\begin{array}{c}\text { Frequency } \\
(\mathbf{n = 1 0 0 )}\end{array}$ & $\begin{array}{c}\text { Percentage } \\
\text { (\%) }\end{array}$ \\
\hline Daily & 5 & 5,0 \\
Weekly & 28 & 28,0 \\
Monthly & 50 & 50,0 \\
Yearly & 6 & 6,0 \\
Don't know & 11 & 11,0 \\
\hline
\end{tabular}

Table 3 The Awareness of participants about breast self examination

\begin{tabular}{lcc}
\hline $\begin{array}{l}\text { The frequency of breast self }- \\
\text { examination }\end{array}$ & $\begin{array}{c}\text { Frequency } \\
(\mathbf{n = 1 0 0 )}\end{array}$ & $\begin{array}{c}\text { Percentage } \\
\text { (\%) }\end{array}$ \\
\hline Not aware & 5 & 5,0 \\
Partially aware & 55 & 55,0 \\
Fully aware & 40 & 40,0 \\
\hline
\end{tabular}

Table 4 The frequency of participants to performed breast self examination

\begin{tabular}{lcc}
\hline $\begin{array}{l}\text { The frequency of Breast Self - } \\
\text { Examination Should Be Performed }\end{array}$ & $\begin{array}{c}\text { Frequency } \\
(\mathbf{n = 1 0 0 )}\end{array}$ & $\begin{array}{c}\text { Percentage } \\
\text { (\%) }\end{array}$ \\
\hline Daily & 1 & 1,0 \\
Weekly & 12 & 12,0 \\
Monthly & 48 & 48,0 \\
Yearly & 23 & 23,0 \\
Never & 16 & 16,0 \\
\hline
\end{tabular}

Table 5 The Answers of Participants About Breast Self Examination Steps

\begin{tabular}{lcc}
\hline $\begin{array}{l}\text { The frequency of Breast Self - Examination } \\
\text { Should Be Performed }\end{array}$ & $\begin{array}{c}\text { Frequency } \\
(\mathbf{n = 1 0 0 )}\end{array}$ & $\begin{array}{c}\text { Percentage } \\
\text { (\%) }\end{array}$ \\
\hline 3 & 9 & 9,0 \\
4 & 11 & 11,0 \\
5 & 29 & 29,0 \\
6 & 21 & 21,0 \\
Don't know & 30 & 30,0 \\
\hline
\end{tabular}

The frequency of participants to performed breast self - examination was presented in Table 4 and the answers of participants about breast self examination steps were presented in Table 5.

\section{DISCUSSION}

Breast cancer is a widely known disease that is famous among female more than 30 years old and above. The study has been made to find out and see whether students are aware of the screening method for breast cancer. Most of the studies carried out in Nigeria stated that participants have inadequate knowledge about the risk factors for breast cancer and breast self-examination (BSE). ${ }^{6}$ These recent study findings are completely different compared with other studies, where the students were found to have moderate knowledge about the risk factors however they are also poor in practicing BSE.

The findings of this study revealed that students in medical faculty at Udayana University has moderate knowledge of the associated breast cancer risk factors. In the present study, had showed that the risk factors that are widely known are family history of breast cancer $(n=82)$, radiation exposure $(\mathrm{n}=75)$, hormonal replacement therapy $(\mathrm{n}=68)$, high fat consumption $(\mathrm{n}=68)$, alcohol consumption $(n=66)$, cigarette smoking $(n=65)$ and stressful life $(n=62)$. Nearly half of the students identified the possible risk factors are oral contraceptives, drug abuse, wearing tight bras, sedentary lifestyle, exposure to the chemical in cosmetic products, irregular menstruation history, a hard blow to the breast and early sexual debut. In this study, it had been discovered the majority of our respondents had moderate knowledge of the risk factors for breast cancer. However, a similar study that carried out by Peace Iheanacho et al. showed that the students had little knowledge of risk factors for breast cancer. Since all of the samples were taken among medical students at Udayana University, they seem to have more information and knowledge about breast cancer compared to the participants in P. Iheanach. ${ }^{3}$ It is because programs about awareness on cancer are widely reached to all medical students every year during August.

94 of the female students in this study reported having heard about breast self-examination, our study revealed that 84 of them know how to perform breast self-examination. However, subsequent findings show that fewer students understand the procedures involved in BSE.

Results of this study show that half of the students at Udayana University has basic knowledge about BSE to perform every month. Another half of them stated that BSE should perform daily (5 students), weekly (28 students), yearly (6 students) and don't know (11 students). Majority of the students did not know the number of steps involved in BSE. It can be deduced that they didn't give much priority to learn further about BSE even though as a medical student, they should keep themselves at check about any recent findings on cancer. The results of the study also agree with P. Iheanacho et al. ${ }^{3}$

The result of this study showed 84 of students stated that they are performing BSE, but only 50 of them performing BSE monthly, 34 of the students were performing irregularly. Students unconcerned 
attitude might be affected by their performance in BSE. These studies propose that the number of teenagers performing BSE monthly is little all over the world. Five students are not aware of BSE. 55 students partially aware and another 40 students fully aware of BSE. It shows most of the students seems too aware of BSE but only a few of them who few of them fully aware of BSE. The study carried out by Singam in 2017 showed $98 \%$ of young women in the Work Area of UPT Blahbatuh II Public Health has low behavior toward BSE. ${ }^{\text {? }}$

There have been many studies all over the world concerning breast cancer and breast self-examination among women. The study carried out by V. Rosolowich et al. stated that Routine teaching of breast self-examination does not reduce mortality and the likelihood of increasing rates of benign biopsy. However, 97 of students agreed that BSE is important as a screening tool for breast cancer. It can be deduced that students are aware of breast self-examination is the easiest and cheapest screening method to find abnormalities in the breast. ${ }^{8}$

\section{LIMITATION}

This research has several weaknesses, the data collection was done by questionnaire method, so there was a possibility of the respondents have been not seriously filled the questionnaire.

\section{CONCLUSION}

This study has revealed moderate knowledge of risk factors for breast cancer and the screening methods as well as the moderate level of practice of breast self-examination among female students in medical faculty at Udayana University. To perform the BSE correctly, the students have to be more concern about relevant education programs that are having around them.

\section{REFERENCES}

1. Komen SG. What is Breast Cancer?. Susan Komen, p. 2. 2015 .

2. World Health Organization. Breast Cancer Prevention and Control. Geneva: World Health Organization. 2013.

3. Iheanacho P. Awareness of breast cancer risk factors and practice of breast self examination among female undergraduates in university of Nigeria Enugu campus. Open Journal of Nursing. 2013. 3(147 - 152), p. 6.

4. Saurabh RS. Self Breast Examination: A Tool for Early Diagnosis of Breast Cancer. American Journal of Public Health Research. 2013. Volume I, p. 6.

5. Aleksandra C. Assessment of pain, acceptance of illness, adjustment to life. GrossMark. 2015. p. 8.

6. Olumuyiwa OO, Tayo. Breast cancer knowledge, attitudes and prarticeamong nurses in Lagos, Nigeria, Acta Oncologica. 2001.

7. Singam K, Wirakusuma I. Gambaran tingkat pengetahuan dan perilaku tentang pemeriksaan payudara sendiri (SADARI) pada remaja putri di wilayah kerja UPT Puskesmas Blahbatuh II Gianyar Bali Indonesia. Intisari Sains Medis. 2017. 8(3): 184-188. DOI:10.15562/ism. v8i3.135.

8. Vera Rosolowich, Breast Self Examination, J Obstet Gynaecol Can. 2006. 28(8):728-730.

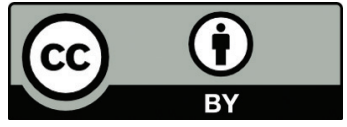

This work is licensed under a Creative Commons Attribution 